\title{
NOTES ON NORTH AMERICAN
}

\section{ANYPHANIN $Æ$}

\author{
IN

\section{THE MUSEUM OF COMPARATIVE ZOOLOGY}

\section{By Elizabeth B. Bryant}

In a recent revision of the spiders of this sub-family in the Museum of Comparative Zoology from North and Central America and the West Indies, it was found that there has been much confusion in the use of genera. The genus Anyphæna was made by Sundevall in 1833 (Conspectus Arachnidum, p. 20) for Aranea accentuata Walckenaer. L. Koch (Die Arach. fam. Drassiden, 1866, p. 194) first called attention to the position of the ventral furrow, "as either in the middle of the length of the abdomen or behind the middle." Nicolet (Say, Hist. de Chili, 1849, 3, p. 450) made the genus Gayenna for the South American species where the posterior spiracular openings are nearer the spinnerets than to the epigastric plate. F. O. P. Cambridge (Biologia Centrali-Americana, 1900,2 , p. 94), definitely restricts the genus to "Spiracular rima situated behind the middle of the ventral area of the abdomen towards the spinners," and states that the genus is not found in Central America. Mr. Banks has used the genus Gayenna when the ventral furrow is behind the middle of the entire abdomen.

The genus Marcellina has been made for Clubiona piscatoria Hentz, known only from two males from Alabama and an immature male from Newton, Massachusetts. The large anterior median eyes, the peculiar palpus, and the short spines on the legs are very different from any other genus.

Hentz, in his descriptions of Clubiona saltabunda and C. albens, questions the generic position. The exaggerated 
length of the legs in both sexes, the difference in the male palpi and the number and arrangement of spines on the legs do not agree with any of the genera from Central America, so the new genus Anyphænella has been made for them.

1. Ventral furrow one-third nearer epigastric plate than to spinnerets Aysha.

Ventral furrow one-third nearer spinnerets than to epigastric plate, anterior median eyes largest

Marcellina

Ventral furrow about midway between epigastric plate and spinnerets, anterior eyes equal or median slightly smaller

2. Anterior tibiæ as long as both cephalothorax and abdomen Anyphænella

Anterior tibiæ normal Anyphæna.

Marcellina gen. $\mathrm{n}$.

Type: Clubiona piscatoria Hentz.

Cephalothorax oval, thoracic groove rather long, front broad and obtuse. Anterior row of eyes slightly recurved, equidistant, median largest of the eight; posterior row procurved and equal; quadrangle higher than wide, wider in front; lateral eyes separated by less than diameter of anterior laterals. Clypeus not as wide as diameter of anterior median eye. First leg longer than fourth; anterior legs with few spines on ventral side. Mandibles of male welldeveloped with two widely separated teeth on superior margin of groove and two teeth on inferior margin. Ventral furrow one-third nearer spinnerets than to epigastric plate.

The genus differs from Gayenna, which has the ventral furrow near the spinnerets, by the large median eyes and from the other American genera by arrangement of the eyes, number of teeth on the mandibles and the shorter spines on the legs. 


\section{Marcellina piscatoria (Hentz)}

Figs. 1, 2

Clubiona piscatoria Hentz, Journ. Boston Soc. Nat. Hist.; 1847, 5, p. 450, pl. 23, f. 15 ; “ ‘ Alabama”; reprint, 1875, p. 84, pl. 10, f. 15, pl. 18, f. 29.

ô $7 \mathrm{~mm}$. long, cephalothorax $3 \mathrm{~mm}$. I leg, $15 \mathrm{~mm}$. long.

Cephalothorax pale yellow without markings, covered with many fine, black hairs; abdomen pale yellow without markings, with many long, fine hairs; legs pale, covered with dark hairs; spines on all legs less than diameter of joint, few and becoming irregular; more spines on upper side of legs than on ventral. Spines, I leg, tibia 2, near middle, 1 lateral, all less than diameter of joint; metatarsus 2-2, 1 lateral. Metatarsus as long as tibia.

Eyes; anterior row recurved, equidistant, A. M. E. largest; posterior row procurved so that lateral eyes are almost touching, equal in size; P. M. E. slightly nearer P. L.E. than to each other and smaller than A.M.E. Clypeus about as wide as diameter of A. L. E.

Mandibles, brown, porrect, one-half the length of cephalothorax, covered with long, black hairs. Two isolated teeth on superior margin and two isolated teeth on inferior margin. Cephalothorax widest between II and III leg and only slightly narrowed in front of I coxae; thoracic groove rather long, sternum triangular, widest between coxae I and II; coxae IV separated by less than half a diameter. Ventral furrow one-third nearer the spinnerets than to the epigastric plate.

Palpus. Femur two-thirds as long as cephalothorax, curved, tibia but little longer than patella, with apophysis near tip, as in figure 1, tarsus longer than femur and prolonged far beyond the palpal organ; embolus prolonged in a fine straight point the length of the tarsus.

2 ô Ala.; Auburn, C. F. Baker coll.; 1 o im.; Mass.; Newton 17 Oct., 1904, E. B. Bryant coll. 


\section{Anyphæna}

Type: Aranea accentuata Walckenaer, 1802.

Cephalothorax oval, thoracic groove rather long, front broad and obtuse. Anterior row of eyes straight or weakly recurved, the median usually the smallest; posterior row weakly procurved, equal and usually equidistant; quadrangle of median eyes higher than wide and narrower in front; lateral eyes well separated. Legs long with scopulæ on all tarsi and often on the anterior metatarsi. Ventral furrow about midway between epigastric plate and spinnerets.

The genus Anyphæna was made by Sundevall in 1833 . (Conspectus Arachnidum, p. 20) for Aranea accentuata Walckenaer. In this species the ventral furrow is a little nearer the epigastric plate than to the spinnerets and there is one pair of spines (basal) on the anterior metatarsi. The A. M. E. are smaller than the A. L. E., the mandibles are vertical, with two teeth on the inferior margin of the groove and the palpus is quite unlike any of the American forms.

In a careful examination of one of the common species (A. celer Hentz), it is found that the position of the ventral furrow often varies from the middle to just in front, or a little behind the middle, so that it is not easy to use as a primary character, but in all species examined the position of the furrow is approximately the same in the two sexes, also the number and arrangement of the spines on the anterior legs. With the exception of $A$. calcar sp. n. from Florida and $A$. aperta Banks from Washington all the American species have two pairs of spines on the first and second metatarsi. The first species also differs in having a large club-shaped process on the patella of the male palpus, a character found on at least one European species.

In 1913 Berland, Araignees de l'Equateur, called attention to the subdivision made by M. Simon in 1903. The first group has two teeth on the inferior margin of the mandibles and the ventral furrow is nearer the spinnerets than to the epigastric plate. The second group, which includes Anyphæna, has several teeth on the inferior margin 
(from 4 to 10), and the ventral furrow is nearer the epigastric plate than to the spinerets. This character of teeth is found variable, as in $A$. laticeps sp. n. there are no teeth on the superior margin of the male and a distinct carina on the inferior margin; and in the female, a carina on the superior margin and no teeth on the inferior margin, yet the male palpus is nearer the type of the genus than any other American species.

With the material available, the genus Gayenna is restricted to species from South America, with the ventral furrow near the spinnerets (at least one-third nearer than to the epigastric plate), and the genus Anyphæna, to species with the ventral furrow near the middle (midway between the epigastric plate and the spinnerets) and usually two pairs of spines beneath the anterior metatarsi. Future study may prove that the American species of Anyphæna may belong to some of the numerous neotropical genera, rather than to the European genus Anyphæna.

It has not been possible to make a satisfactory key for the females of the genus. Possibly when both sexes of all species are known, some character can be recognized by which they can be separated, but at present they can be identified only by the vulva. In both sexes the number and position of spines on the anterior legs is the same.

\section{Anyphæna}

\section{Males}

1. I metatarsus 1-1 spines, head broad, mandibles geniculate, large club-shaped spur on patella of palpus calcar sp. n.

I metatarsus $2-2$ spines

2.

2. Head but little narrowed in front of I coxae, mandibles porrect, cephalothorax shining chestnut brown

laticeps sp. n.

Head less than half as wide as cephalothorax between II and III legs, cephalothorax never brown

3. 
3. II, III and IV coxae modified …........................ 4 . All coxae normal .............................................. 5 .

4. III coxae with posterior spur bifid and with central process of palpus broad....................... pectorosa Koch. III coxae with posterior spur slender and curved and with central process of palpus slender fraterna Banks.

5. III leg modified ................................................. 6. III leg normal ............................................. 9.

6. III tibia with 2 short, stout spines on ventral, posterior margin .............................................. 7. III tibia with but 1 short, stout spine on ventral posterior margin ................................................ 8.

7. Dorsal section of tibial apophysis of palpus broad and triangular ....................................................eler Hentz

Dorsal section of tibial apophysis slender and sharp maculata Banks.

8. Tip of ventral part of tibial apophysis fairly broad and bifid and upper part reduced to a small, sharp point scarcely noticeable ..................coloradensis $\mathrm{sp} . \mathrm{n}$. Tip of ventral part of tibial apophysis rather slender and notched, and the upper lobe fairly large, pointed and triangular ............................crebrispina Chamb.

9. Distal apophysis of tibia ending in a simple, sharp point, tibia twice length of patella...........ruens Chamb. "Distal apophysis in form of undivided chitinous lamina and narrowing distad, but with apex subtruncate and weakly notched at middle". saniuana Chamb.

Anyphæna calcar sp. $n$.

FIG. 3

ô $4 \mathrm{~mm}$. long; cephalothorax $1.7 \mathrm{~mm}$.

Cephalothorax yellowish, darker in front with white hairs on head; abdomen pale yellow with many dark spots and streaks, which unite in the posterior median part to form a series of chevrons; legs yellowish with faint traces 
of dark spots; spines, I leg; tibia 2-2, second pair at about middle of joint, 2 lateral; metatarsus 2, 1 lateral, scopulae very scant on anterior tarsi and metatarsi.

Anterior row of eyes slightly recurved, equidistant, A. M. E. smallest; posterior row longer than anterior, P. M. E. slightly nearer P. L. E. than to each other, P. M. E. largest; quadrangle higher than distance between P. M. E. eyes. Clypeus narrow, scarcely more than diameter of A. M. E. eyes. Mandibles vertical, with many long, black hairs ; superior margin of fang groove, a denticulate carina; inferior margin a group of five minute teeth near median edge.

Ventral furrow midway between spinnerets and epigastric plate.

Palpus. Patella and tibia of equal length, the former with a large club-shaped spur on the outer side, nearly as long as the joint; tibia with a long apophysis resting against the palpus, ending in a sharp spine; the ventral side of the tibia has a pronounced keel two-thirds the length of the joint. The upper half of the palpal organ has a large white sack with a slender white filament at the upper end and a tube from the lower part which bends and disappears in the upper part of the organ. On the inner side is a piece ending in a sharp point a little above the white sack, and in the opposite side is a slender piece ending in a curved hook.

Type: 3 ô Fla.; Dunedin, 1927, W. S. Blatchley coll.

This is the only American species of Anyphæna with a spur on the patella.

Anyphæna laticeps sp. $\mathrm{n}$.

Figs. 4, 24

ô $4 \mathrm{~mm}$. long; cephalothorax $1.5 \mathrm{~mm}$., abdomen $2.5 \mathrm{~mm}$.

Cephalothorax shining chestnut brown, a little darker about the eyes; abdomen greenish gray; legs little lighter in color than cephalothorax, long and slender with darker bands at middle and end of tibia. Spines, I tibia 2-2, long 
and slender, no lateral, metatarsus 2-2, long and slender, no lateral.

Eyes : anterior row straight, equal and equidistant; posterior row slightly procurved, longer than anterior row, P. M. E. little nearer P. L. E. than to each other; laterals separated by radius of P.L. E.; quadrangle as high as distance between P. M. E. Clypeus a little wider than diameter of anterior eyes.

Mandibles dark, porrect and more than half as long as cephalothorax, no teeth on superior margin of groove, distinct denticulate carina on inferior margin; fang long and sinuate; labium longer than wide, half as long as maxillæ, and deeply notched.

Cephalothorax, narrowed but little in front of I coxae. Sternum twice as long as broad, widest between II coxae. Ventral furrow a little nearer epigastric plate than to spinnerets.

Palpus. Tibia twice as long as patella, apophysis onethird length of tibia and pressed close to tarsus. Palpal organ nearly fills the cavity.

o $4.2 \mathrm{~mm}$. long.

Cephalothorax shining chestnut brown, darker about the eyes and with scattered white hairs on sides; abdomen pale yellow with irregular dark marks arranged to form broken chevrons; venter pale; legs lighter in color than cephalothorax without the dark bands and spines as in male.

Eyes as in male. Mandibles dark brown and geniculate; carina on superior margin of groove and no teeth on inferior margin. Cephalothorax narrowed but little in front of I coxae. Sternum light and shining, nearly twice as long as broad. Ventral furrow a little nearer epigastric plate than to spinnerets. Epigynum dark with two broad openings below two pairs of dark spots.

Type: î $q$ Ga.; Thompson's Mills, H. Allard coll.

Paratypes. 1 \& Va.; Falls Church, N. Banks coll.; 1 q Ala.; Auburn, C. F. Baker coll.

The dark color of the cephalothorax would seem to ally this species to $A$. striata Becker, but the description of 
that species would indicate a much larger spider, possibly an Aysha.

The two following species are separated in the males by the modified posterior coxae.

\section{Anyphæna pectorosa L. Koch}

FIG. 5 .

Die Arach. fam. Drassiden, 1866, p. 198, pl. 8, f. 131, "1 ô Baltimore."

Anyphæna calcarata Emerton, Trans. Conn. Acad. Sci.; 1890, 8, p. 189, p. 6, f. 3, " o क ㅇ Conn.; West Haven, July .... N. Pike's Long Island Collection."

The IV coxae in the males have a small, pointed process directed outward; the III coxae have two processes, the posterior one is pointed inward and distinctly bifid, the anterior process is a blunt tooth. The principal process in the palpus is broad and flattened. On the upper side of the tibia is a small spine.

This species is found from Massachusetts south to North Carolina and Tennessee and west to Missouri.

\section{Anyphæna fraterna (Banks)}

Figs. 6, 23

Gayenna fraterna Banks, Trans. Amer. Ent. Soc.; 1896, 23, p. 63. " o near Sea Cliff, N. Y. June."

Anyphæna conspersa Keyserling, Verh. Zool. bot. Ges. Wien 1887, 37, p. 453, pl. 6, f. 23 "ㅇ Ky.; Bee Spring," preoccupied by Simon, 1878.

This species is distinctly spotted. In the male the posterior process on the III coxae is slender and simple, not bifid as in $A$. pectorosa. In the palpus the largest process is slender and curved only at the tip. The tibia has a small cone-shaped process on the inner basal side as well as a short spine on the upper. The epigynum is long and narrow instead of broad as in pectorosa.

Type. 2 o N. Y.; Sea Cliff, N. Banks Coll. Found from Massachusetts to Tennessee and Kentucky. 
The four following species form a natural group, with the third leg in the male modified, with the third femur enlarged, and one or two stout, cone-shaped spines on the posterior ventral side of the tibia. In both sexes there is a distinct dark ring near the distal end of each femur.

\section{Anyphæna celer (Hentz)}

Figs. 7, 25, 28

Clubiona celer Hentz, Journ. Boston Soc. Nat. Hist.; 1847, 5, p. 452, pl. 23, f. 20 ; reprint, p. 87, pl. 10, f. 20. "North Carolina, Alabama."

Anyphæna incerta Keyserling, Verh. zool. bot. Ges. Wien, 1887, 37, p. 452, pl. 6, f. 22. " q Mass.; Cambridge."

A widely distributed species found under dead leaves from New England to Texas. The position of the ventral furrow varies from mid-way between the spinnerets and the epigastric plate and nearer to the epigastric plate. The under side of the tibia of the third leg has two very short spines on the posterior side.

A common species from Massachusetts south to Texas.

\section{Anyphæna maculata (Banks)}

Figs. 8, 31

Gayenna maculata Trans. Amer. Ent. Soc.; “ث D. C.; Washington." 1896, 23, p. 64. S. C. Bishop and Crosby, Journ. Mitch. Soc. 1926, 46, p. 189, pl. 24, f. 37, 38.

Crosby and Bishop give a very full description of the male, but fail to mention the enlarged third femur and the two stout spines on the tibia of the third leg. The palpus is very similar to that of $A$. celer, but the tibial apophysis is quite distinct. The upper branch is shorter and ends in a sharp point, and the inner branch is a thin leaf-like plate, folded almost double. The large rounded protuberance on the basal half is larger and more conspicuous than in $A$. celer.

Type: ․ D. C. Washington. 
$\hat{o} \quad$ $~ N$. Y. ; Sea Cliff, N. Banks Coll.; ô Va.; Falls Church, N. Banks Coll. 1 \& Ky.; Hart Co.; Rio. A. F. Archer coll.

Anyphæna coloradensis sp. n.

Figs. 9, 10, 30, 33

ô $4.5 \mathrm{~mm}$. long.

Cephalothorax light brown with faint dark marks from the lateral eyes to the posterior margin; abdomen light yellow with five median dark bars slightly bent as chevrons, sides and venter with dark spots and streaks; sternum light; legs light with dark spots at base of spines; spines I leg, tibia, 2-2-2 none apical, 2 lateral, metatarsus, 2-2, 2 lateral, metatarsus shorter than tibia; coxae III and IV densely, minutely, spinulate, femur III enlarged and on ventral surface, minutely spinulate; two long spines on dorsal surface and one very short, stout spine on posterior, tibia III two long spines on anterior edge and one stout spine posteriorly, two lateral. Ventral furrow is nearer spinnerets than to epigastric plate. Eyes; anterior row recurved, A. M. E. smallest and less than their diameter apart, and less than radius from the A. L. E.; posterior row procurved, P. M. E. nearer P. L. E. than to each other; laterals separated by less than radius of A. L. E.; quadrangle nearly twice as high as distance between posterior median.

Palpus: Patella as long as tibia; tibial apophysis prolonged half the length of the tarsus, with upper edge serrate, with one distinct tooth midway, palpal organs filling the entire cavity and similar to A. celer.

\section{o $4.7 \mathrm{~mm}$. long.}

Markings the same as in the male, but not quite as distinct, except on the legs where the dark marks are more pronounced. The posterior coxae are not roughened or the III femur enlarged. Eyes same as in the male. Epigynum as figured.

Type: 1 ô, 2 ô Col.; Boulder, T. D. A. Cockerell coll. N. Banks Coll. 


\section{Anyphæna crebrispina Chamberlin}

Fig. 11

Pomona Coll. Journ. Ent. Zool.; 1919, 12, p. 10, pl. 4, f. 4. “o Cal.; Claremont”, No. 353.

The third tibia has but one stout spine on the posterior side. The tibial apophysis has the lower branch about onethird the length of the tarsus, with a distinct notch at the tip and the upper lobe in a pointed triangle.

Type: 1 o Cal.; Claremont, R. V. Chamberlin Coll. This is probably the male of Anyphæna californica (Banks) as the later has been found at Claremont.

\section{Anyphæna ruens Chamberlin}

Pomona Coll. Journ. Ent. Zool.; 1919, 12, p. 11, pl. 5, f. 1. “ o Cal.; Claremont, April, 1913, No. 352." Anyphæna mundella Chamberlin, ibid, p. 12, pl. 5, f. 3. \& nec ô "Cal.; Claremont."

In the original description of $A$. mundella the female only was described and the palpus of the male figured. On examining the specimens, the two obviously belong to different genera. The male has but one pair of spines on the anterior metatarsi, a broad low cephalic region and the ventral furrow quite near the epigastric plate, all characters of Aysha. The female has two pairs of spines on the anterior metatarsi, the narrow and high cephalic portion and the ventral furrow at "middle or slightly behind middle of abdomen." In all species of Anyphæna seen the number of spines on the anterior legs, shape of cephalothorax and the position of the ventral furrow is the same in both sexes.

Type: 1 of M. C. Z. no. 352, Cal.; Claremont. 1 \% M. C. Z. no. 348 , Cal.; Claremont.

A B. C. ; Victoria, Taylor coll.; ô $\&$ Cal.; Claremont; C. F. Baker coll.; Mt. Helens; 8 July, 1918. Helen Van Duzee coll. 
The following species are known only from females.

\section{Anyphæna aperta (Banks)}

FIG. 35

Gayenna aperta Banks, Proc. Cal. Acad. Sci.; 1921, 11, p. 100, f. 3. "q Wash.; Olympia."

The ventral furrow is midway between epigastric plate and spinnerets. The spines on I tibia 2-2-2 (one pair distal), 2 lateral, metatarsus 2, 2 lateral.

Type: 1 \% Wash.; Olympia, T. Kincaid coll. 1 \% Wash.; Blakley Is.; 8 July 1928. L. G. Worley coll.

\section{Anyphæna californica (Banks)}

Gayenna californica Banks, Proc. Cal. Acad. Sci.; 1904, 3, p. 338, pl. 38, f. 2. "o Palo Alto, Mill Valley."

Anyphæna intermontana Chamberlin, Can. ent.; 1920, 52 , p. 200, f. 6 .

Type: 1 \& Cal.; Palo Alto, R. W. Doane coll.

1 \& Cal.; Marin Co.; Ross, 3 \& Claremont, N. Banks Coll. 2 \& Utah; Mill Creek, R. V. Chamberlin coll.

\section{Anyphæna fragilis Banks}

FIG. 32

Can. Ent.; 1897, 29, p. 194 " क Fla.; Jacksonville."

Gayenna parvula Banks, Proc. Ent. Soc. Wash.; 1899, 4, p. 191. "o La.; Shreveport."

Cephalothorax brown, darker about the eyes with scattered white hairs, cephalic groove short; abdomen pale, sometimes with a few marks bent almost to form chevrons posteriorly; venter pale without marks; legs pale, sometimes with traces of two dark rings on anterior tibiae, and at end of metatarsi. Spines; I leg, tibia, 2-2, long, no lateral metatarsus, 2-2, long, no lateral. Cephalothorax very broad at anterior margin, with only a slight narrowing in front of coxae I. Mandibles geniculate and very dark brown, covered short hairs. 
Eyes; anterior row straight, equidistant and A. M. E. a little smaller than A. L. E.; posterior row procurved, equal and P. M. E. a little nearer to P. L. E. than to each other. Quadrangle but little higher than wide and narrowed in front. Clypeus low, but little wider than diameter of A. M. E. Ventral furrow a little nearer epigastric plate than to spinnerets.

Type: 2 \&, 1 i im. Fla.; Jacksonville; 2 \& La.; Shreveport. N. Banks Coll.; 1 \& Ga.; Bainbridge, J. C. Bradley coll.

\section{Anyphæna pacifica (Banks)}

FIG. 36

Gayenna pacifica Banks, Trans. Amer. Ent. Soc.; 1896, 23, p. 63. "q Wash.; Olympia."

Type: 3 o, 1 o $\mathrm{im}$. Wash.; Olympia, J. Kincaid coll.; 1 o Idaho; Moscow Mts., 29 Oct. 1910. J. A. Hyslop coll.; 2 \& Wash.; Wawawai, W. M. Mann coll.; 1 \& Cal.; Mt. Tamalpais, Cal. Acad. Sci. Coll.

\section{Anyphæna zina Chamberlin}

Pomona Coll. Journ. Ent. Zoöl.; 1919, 12, p. 11, pl. 4, f. 5. Type: 1 o Cal.; Claremont, R. V. Chamberlin coll.

\section{Anyphænella gen. n.}

Type: Clubiona saltabunda Hentz.

Eyes similar to Anyphaena; A. M. E. smaller than A. L. E. Mandibles vertical on both sexes, with row of many minute teeth on the inferior margin, and a row of four distinct teeth on the superior margin. First leg longest and tibia longer than or nearly as long as the entire length of spider. Two pairs of spines beneath I tibia and two pairs beneath I metatarsus. Ventral furrow about midway between spinnerets and epigastric plate.

It differs from Wulfila in the number of spines on the metatarsi and from Sillus in the much longer legs and the structure of the male palpi. 


\section{Anyphænella saltabunda (Hentz)}

Figs. 18, 22

Clubiona ? saltabunda Hentz, Journ. Boston Soc. Nat. Hist.; 1847,5 , p. 453 , pl. 23, f. 23; "Alabama". reprint, p. 89, pl. 10, f. 23, pl. 18, f. 19.

Anyphæna saltabunda Emerton, Trans. Conn. Acad.; 1890, 8, p. 187, pl. 6. f. 4.

ô $3.5 \mathrm{~mm}$. long; \& $4 \mathrm{~mm}$. long.

Cephalothorax, abdomen and legs light yellow with gray, broken stripes on cephalothorax, and a broken marginal band; two parallel rows of gray dots on the abdomen. Sternum light with a scalloped dark mark around edge. Legs very long and slender. I metatarsus as long as I tibia. Spines, I tibia, 2-2-2. 2 lateral ; metatarsus, 2-2, 3 lateral.

Front less than half the width of cephalothorax between III legs. Eyes; anterior row straight, A. M. E. smallest; posterior row procurved, equal, P. M. E. nearer P. L. E. than to each other; lateral eyes almost touching. Clypeus width of A. M. E. Mandibles small and vertical, with four teeth on superior margin and with many, minute ones on the inferior. Labium slightly notched. Ventral furrow midway between epigastric plate and spinnerets.

Palpus: tibia more than twice as long as patella, much bent and the apophysis near the base.

Epigastric plate extends nearly across the abdomen.

Found from Massachusetts to Florida and west to Wyoming.

\section{Anyphænella alba (Hentz)}

FIGs. 20, 21

Clubiona ? albens Hentz. Journ. Boston Soc. Nat. Hist.; 1847, 5, p. 454, pl. 23, f. 24 ; “Alabama" reprint, p. 89, pl. 10, f. 24, pl. 18, f. 32 .

Chiracanthium albens Hentz, Banks, Proc. Phila. Acad.; 1904, p. 123.

ô $4.5 \mathrm{~mm}$. long; o $4 \mathrm{~mm}$.

Cephalothorax, abdomen and legs almost colorless and without markings. Legs very long and slender, I metatar- 
sus longer than I tibia. Spines, I tibia, 2-2, 2 lateral, metatarsus 2-2, 2 lateral. Eyes; anterior row slightly recurved, A. M. E. smallest and less than a diameter apart, and nearer to each other than to the A. L. E.; posterior row, procurved, equal and equidistant, oval and surrounded by black, quadrangle much higher than wide, anterior side about half as wide as posterior. Mandibles small and vertical. Ventral furrow a little nearer epigastric plate than to spinnerets.

o D. C. ; Washington, N. Banks Coll.; Va.; Falls Church, N. Banks Coll.; N. C. Raleigh, C. S. Brimley coll. Aug. 1916. 1 \& Ky.; Bee Spring, F. G. Sanborn; 1 \& Fla.; Sebastian, 17 Apr. 1919, G. Nelson coll.

\section{Aysha}

Type: Aysha prospera Keyserling.

Cephalothorax low and broad, only slightly narrowed in front of the first coxae. Posterior row of eyes almost straight, anterior row subequal; clypeus about as wide as diameter of anterior median eye. First leg usually longer than fourth, one pair of spines beneath on first metatarsi. Ventral furrow near epigastric plate, at least one-third nearer than to spinnerets. The male palpus has the embolus in a sweeping circular curve, and the epigynum with a distinct circular chitinous rim.

F. O. P. Cambridge states (Biol. Cent. Amer., 1900, 2, p. 98), that the lower fang groove of the mandible has 3-7 teeth. In $A$. cambridgei sp. n. there are no teeth on the lower groove, and the upper groove has a denticulate carina, instead of the usual three or four distinct teeth.

\section{Males}

1. Tibia of palpus with 1 spur ................................... 2

Tibia of palpus with 2 spurs ................................ 5

2. Tibia much longer than tarsus, spur bifid at tip longipalpus sp. $\mathrm{n}$.

Tibia plainly not longer than tarsus 
3. Tibia shorter than tarsus, spur as long as tibia. I tibia 2-2. 1 lateral, metatarsus 2, 1 lateral ...gracilis Hentz Tibia about as long as tarsus, spur shorter than tibia 4

4. I leg, tibia 2-2-2. 2 lat., metatarsus 2, 1 lateral. Spur with large hook at tip velox Becker. I leg, tibia, 2-2, no lat., metatarsus 1-1, no. lat., spur sinuous with minute hook at tip.......cambridgei sp. n.

5. Upper spur as long as tibia and with rest of joint as long as tarsus......................................minuta Camb. Upper spur shorter than tibia but with tibia longer than tarsus decepta Banks

\section{Aysha longipalpus sp. n.}

Fig. 12

ô $10 \mathrm{~mm}$. long. ceph. $4 \mathrm{~mm}$.

Cephalothorax light brown with scattering white hairs; abdomen light grey without markings; legs light brown, first and second darkest. Spines, I, leg, tibia, 2-2-2, (one pair distal), no lateral; metatarsus, 2, no lateral. I femur $5 \mathrm{~mm}$., patella $1.5 \mathrm{~mm}$.; tibia $7.5 \mathrm{~mm}$., metatarsus $8 \mathrm{~mm}$., tarsus $2 \mathrm{~mm}$. Eyes; anterior row slightly recurved, equal and equidistant; posterior row procurved, equal and equidistant; lateral eyes radius of P. L. E. apart. Clypeus slightly more than radius of anterior eyes. Mandibles porrect, two-thirds as long as cephalothorax; four teeth on superior margin and a row of minute teeth on inferior margin; fang long; sternum widest between II and III coxae and prolonged between the IV coxae. Ventral furrow very near epigastric plate.

Palpus. Tibia much longer than tarsus and more than twice as long as patella; very slender, apophysis bifid at tip and little longer than diameter of the segment. Appendages of the palpal organ confined to the upper half of the bulb.

Type: 1 o Costa Rica; San Jose, Valerio coll.

Differs from A. tenuis (L. Koch) Fig. 19, by the longer and more slender tibia, notched tibial apophysis and smaller palpal organ. 


\section{Aysha gracilis (Hentz)}

Figs. 13, 26

Clubiona gracilis Hentz, Journ. Boston Soc. Nat. Hist.; 1847, 5, p. 452 , pl. 23 , f. 19 ; reprint, p. 86 , pl. 10, f. 19 , pl. 18, f. 8. "North Carolina, Alabama."

Anyphæna rubra Emerton, Trans. Conn. Acad., 1890, 8, p. 186, pl. 6, f. 1. “o, Massachusetts and Connecticut and in Pike's Long Island Collection." ibid, 1909, 14, p. 220, pl. 9 , f. 8.

Aysha orlandensis Tullgren. Bih. Svensk. Akad.; 1901, 27, p. 19. f. 4. “\& Fla.; Orlando."

A widely distributed species from Massachusetts to Florida and as far west as Nebraska.

\section{Aysha velox (Becker)}

Figs. 14, 34

Anyphæna velox Becker, Ann. Soc. Ent. Belg.; 1879, 22, p. 83, pl. 2, f. 5-7. \& "Mississippi ; near Pascagoula."

Anyphæna floridana Banks, Trans. Amer. Ent. Soc.; 1896, 23, p. 63. "o Fla.; Lake Worth."

Chiracanthium falculum Chamberlin, Bull. Mus. Comp. Zoöl.; 1925, 67, p. 220. " ô Fla.; Sebastian."

The type, a female, is from Miss. It is the common Aysha in Florida, Alabama and Louisiana, and is found in Bermuda, Cuba and was found by Mr. Banks on Taboga Island, Panama, 29 June, 1925.

\section{Aysha cambridgei sp. $n$.}

FIG. 15

of $8.5 \mathrm{~mm}$. long; ceph. $3 \mathrm{~mm}$.

Cephalothorax light brown; abdomen yellowish grey without markings; legs light brown, lighter than cephalo- 
thorax. Spines, I leg, tibia 2-2, no lateral, metatarsus 2, no lateral. I femur $4 \mathrm{~mm}$., patella $1.8 \mathrm{~mm}$., tibia $4.8 \mathrm{~mm}$.; metatarsus $4 \mathrm{~mm}$., tarsus $2 \mathrm{~mm}$. Eyes; anterior row slightly recurved, equal and equidistant, posterior row procurved, equal and equidistant, lateral eyes separated by diameter of P.L.E. Posterior eyes not surrounded by black. Mandibles brown, less than one-half as long as cephalothorax; porrect; denticulate carina on superior margin and teeth and carina lacking on inferior margin. Maxillæ much broadened above the emargination, labium notched at tip. Sternum twice as long as broad.

Palpus. Tibia not as long as tarsus Apophysis twothirds as long as tibia ending in a small hook. Appendages of palpal organ filling three-quarters of upper portion of tarsus.

Type: 1 o Mexico; Guanajuato. N. Banks coll.

The palpus is similar to A. velox Becker, but differs in the larger and heavier tibial apophysis. The spines on the anterior legs are quite different, also the teeth on the mandibles.

\section{Aysha minuta F. O. P. Cambridge}

FIG. 17

Biol. Cent. Amer. 1900, 2, p. 99, pl. 7, f. 18, 19. M. C. Z. Coll. 1 ô Mex.; Mexico City. 1 \& Costa Rica, San Jose. Tristan Coll.

\section{Aysha decepta (Banks)}

Figs. 16, 27

Anyphæna decepta Banks, Proc. ent. soc. Wash.; 1899, 4, p. 190. " \& La., Shreveport; Texas, Brazos Co."

Anyphæna incursa Chamberlin, Pomona Coll. Journ. Ent. Zool.; 1919, 12, p. 12, pl. 5, f. 2. "क Cal.; Claremont."

Anyphæna mundella Chamberlin, ibid, p. 12, pl. 5, f. 4. ô nec. \&. "Cal.; Claremont." 
Anyphæna johnstoni Chamberlin, Proc. Cal. Acad., 1924. 12, p. 662, f. 105, 106. Gulf of California.

Found in Louisiana, Texas and California. This species may prove to be Aysha simplex Cambridge, Biol. Cent. Amer., 1897, 1, p. 227, pl. 29, f. 4, 5. Panama, Veraguas. Cambridge says, "Palpi, short, slender, cubital joint short, not half the length of the radial, which is very lightly curved, cylindrical, furnished with a few long, slender spine-like bristles, and has a tapering somewhat sinuous reddish-yellow brown apophysis projecting nearly at right angles to the joint at its fore extremity on the outer side. This apophysis is longer than the width of the joint."

In the Spiders of Porto Rico, Trans. Conn. Acad.; 1930, 31, p. 61, Mr. Petrunkevitch has placed Aysha simplex Cambridge as a synonym of Aysha tenuis L. Koch. From the number of specimens in the Museum of Comparative Zoology collection from various islands in the West Indies, the tibia of the male palpus of Aysha tenuis is longer than the tarsus, and at least five times as long as the diameter; there is but one tibial apophysis, not two, which is comparatively short, the embolus occupies the upper half of the palpal organ.

From the two figures of Aysha simplex Cambridge, the tarsus is longer than the tibia, which is about three times the diameter; there are two apophyses and the embolus occupies more than half the palpal organ. It differs from Aysha decepta (Banks) by the shorter upper apophysis and the relatively smaller palpal organ.

\section{Aysha nigrifrons (Chamberlain and Woodbury)}

Anyphæna nigrifrons Chamberlain and Woodbury, Proc. Biol. Soc. Wash.; 1929, 42, p. 137, pl. 1, f. 4 . क "Utah, St. George, Dec. 1925."

The figure of the epigynum, number of teeth on the inferior margin of the mandibles and number of spines on the anterior metatarsi show that this species is an Aysha rather than Anyphæna. 


\section{Plate 6}

Fig. 1. Marcellina piscatoria (Hentz) lateral view of left palpus.

Fig. 2. Marcellina piscatoria (Hentz) dorsal view of eyes.

Fig. 3. Anyphæna calcar sp. n. ventral view of palpus.

Fig. 4. Anyphæna laticeps sp. n. ventral view of palpus.

Fig. 5. Anyphæna pectorosa L. Koch lateral view of palpus.

Fig. 6. Anyphæna fraterna (Banks) lateral view of palpus.

Fig. 7. Anyphæna celer (Hentz) lateral view of palpus.

Fig. 8. Anyphæna maculata (Banks) lateral view of palpus.

Fig. 9. Anyphæna coloradensis sp.n. lateral view of palpus. Fig. 10. Anyphæna coloradensis sp. n. ventral view of palpus.

Fig. 11. Anyphæna crebispina Chamberlin lateral view of palpus.

\section{Plate 7}

Fig. 12. Aysha longipalpus sp. n. lateral view of palpus.

Fig. 13. Aysha gracilis (Hentz) lateral view of palpus.

Fig. 14. Aysha velox (Becker) lateral view of palpus.

Fig. 15. Aysha cambridgei sp. n. lateral view of palpus.

Fig. 16. Aysha decepta (Banks) lateral view of palpus.

Fig. 17. Aysha minuta Cambridge lateral view of palpus.

Fig. 18. Anyphrnella saltabunda (Hentz) lateral view of palpus.

Fig. 19. Aysha tenuis (L. Koch) lateral view of palpus.

Fig. 20. Anyphænella alba (Hentz) epigynum. 
Fig. 21. Anyphænella alba (Hentz) lateral view of palpus. Fig. 22. Anyphænella saltabunda (Hentz) epigynum.

\section{Plate 8}

Fig. 23. Anyphæna fraterna (Banks) epigynum.

Fig. 24. Anyphæna laticeps sp. n. epigynum.

Fig. 25. Anyphæna celer (Hentz) third left leg.

Fig. 26. Aysha gracilis (Hentz) epigynum.

Fig. 27. Aysha decepta (Banks) epigynum.

Fig. 28. Anyphæna celer (Hentz) epigynum.

Fig. 29. Anyphæna californica (Banks) epigynum.

Fig. 30. Anyphæna coloradensis sp. n. epigynum.

Fig. 31. Anyphæna maculata (Banks) epigynum.

Fig. 32. Anyphæna fragilis Banks epigynum.

Fig. 33. Anyphæna coloradensis sp. n. third left leg.

Fig. 34. Aysha velox (Becker) epigynum.

Fig. 35. Anyphæna aperta (Banks) epigynum.

Fig. 36. Anyphæna pacifica (Banks) epigynum. 
Psyche, 1931

Vol. 38, Plate 6

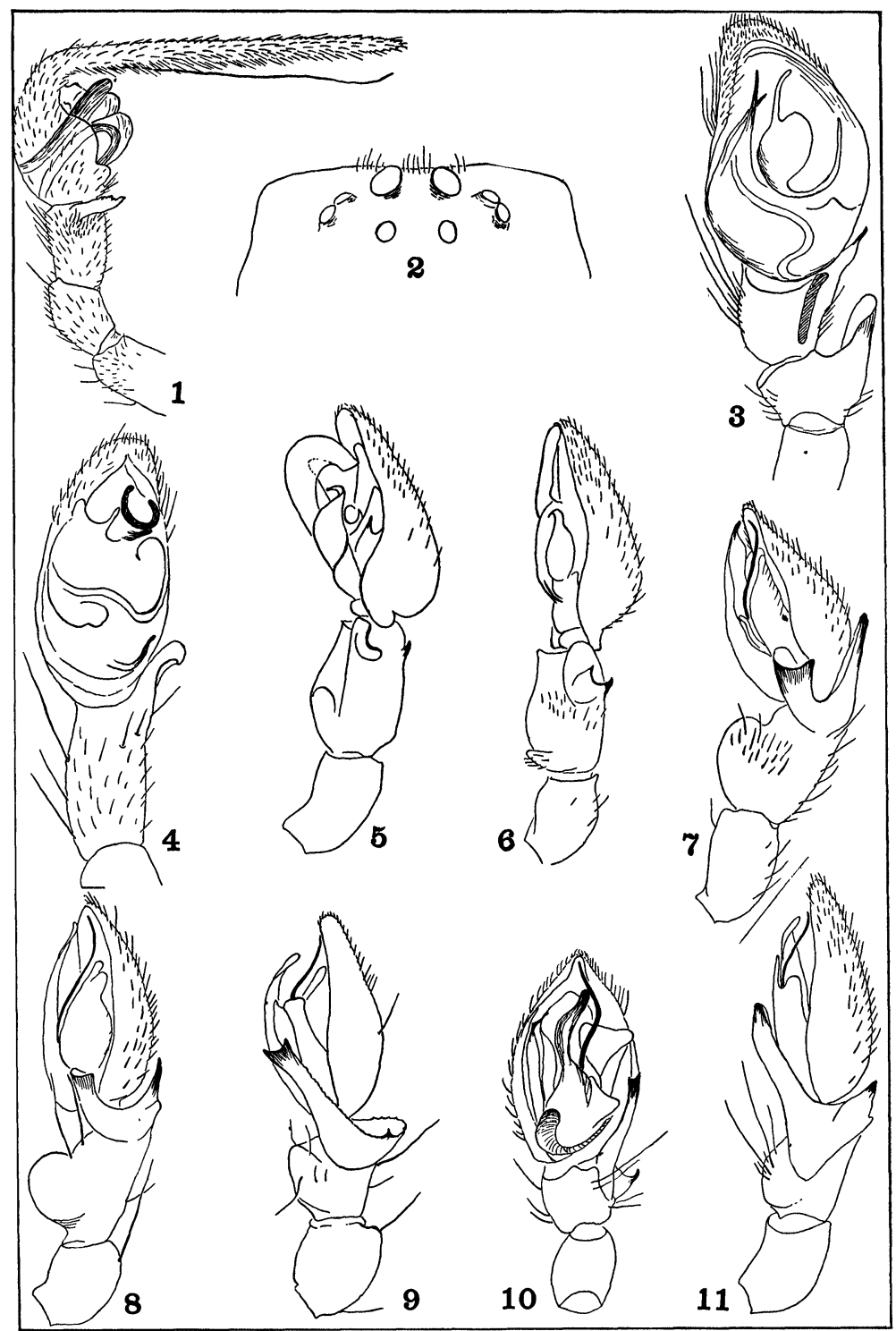

Bryant, Anyphæninæ 
Psyche, 1931

Vol. 38, Plate 7

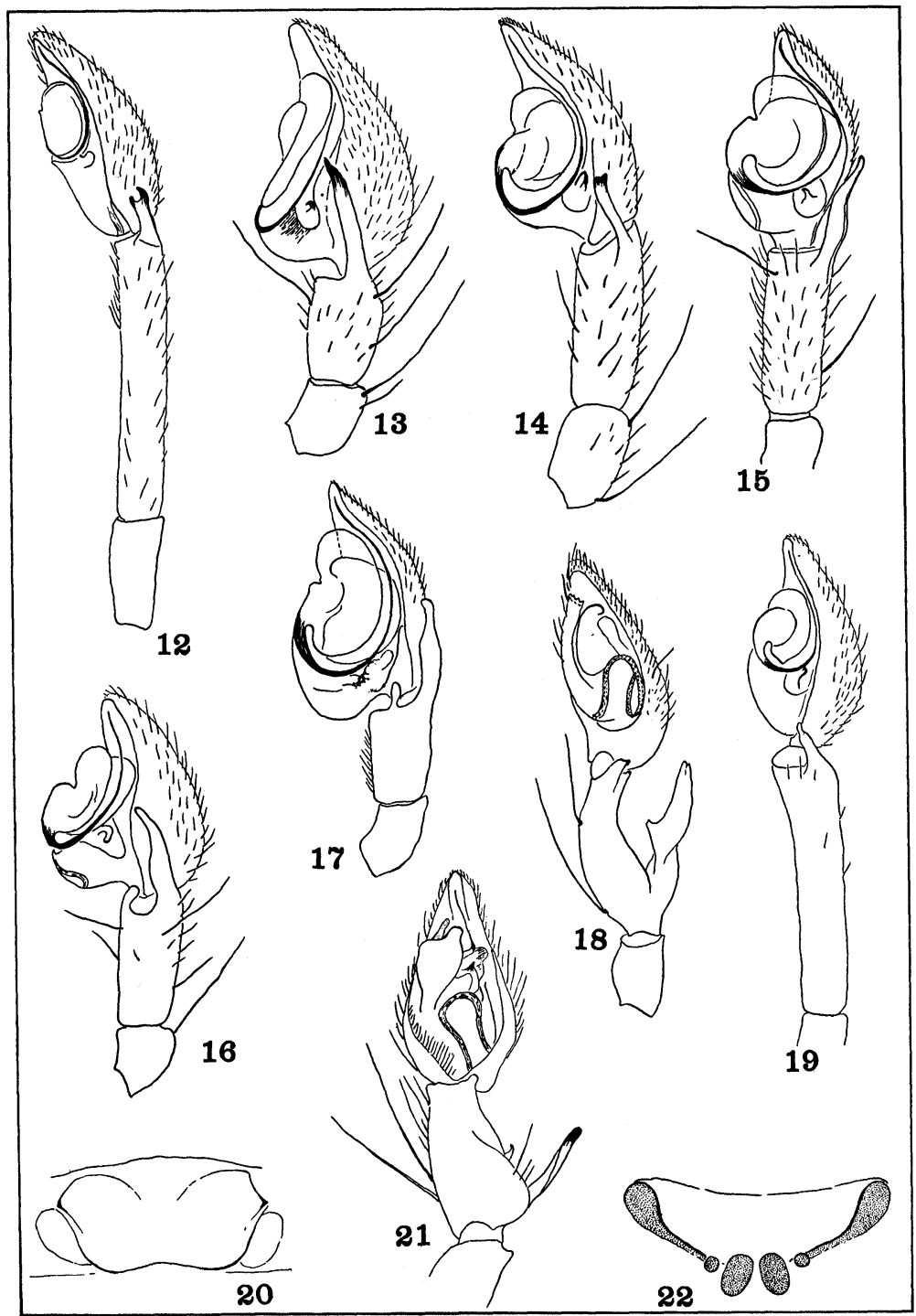

Bryant, Anyphæninæ 
Psyche, 1931

Vol. 38, Plate 8

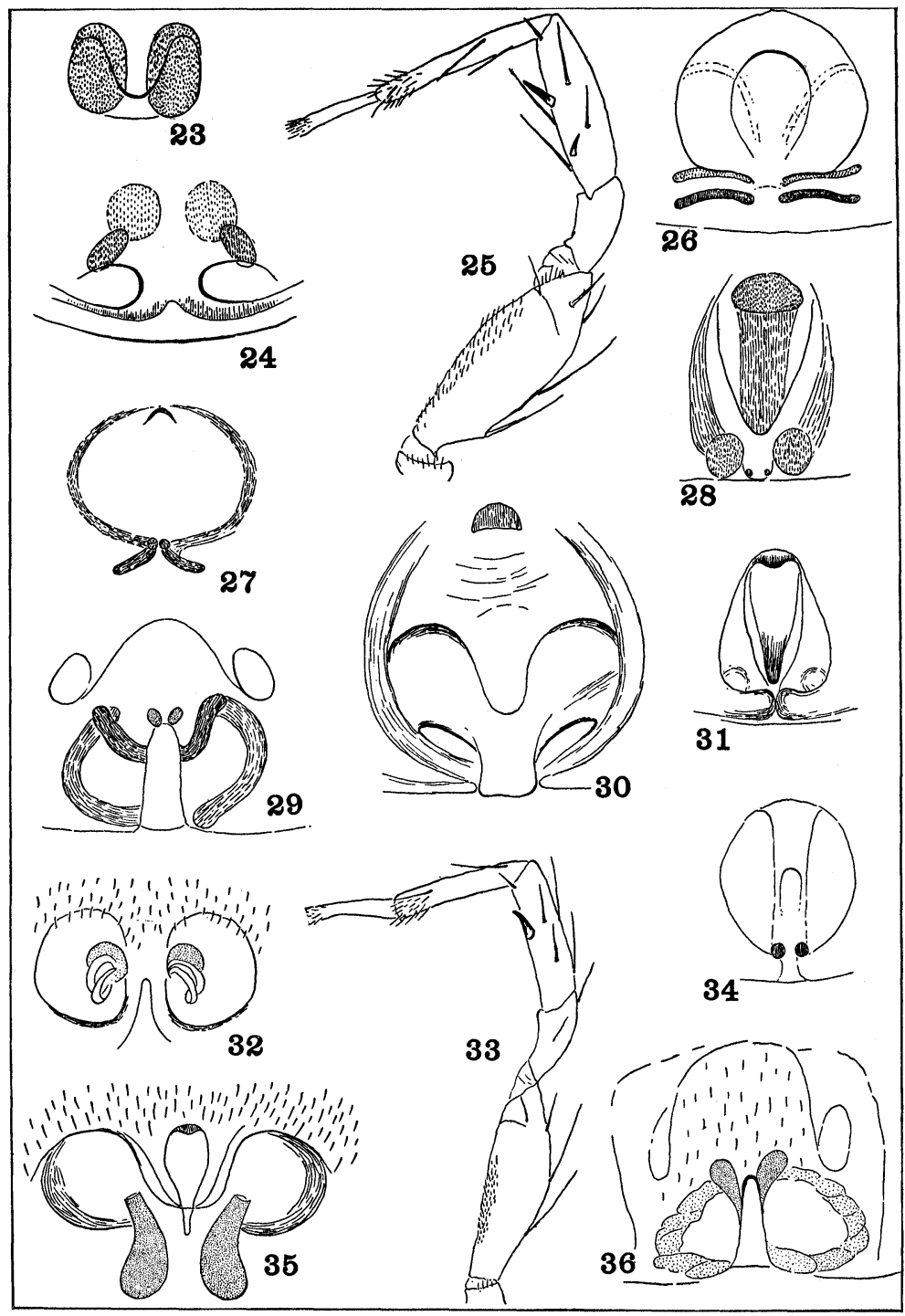

Bryant, Anyphæninæ 

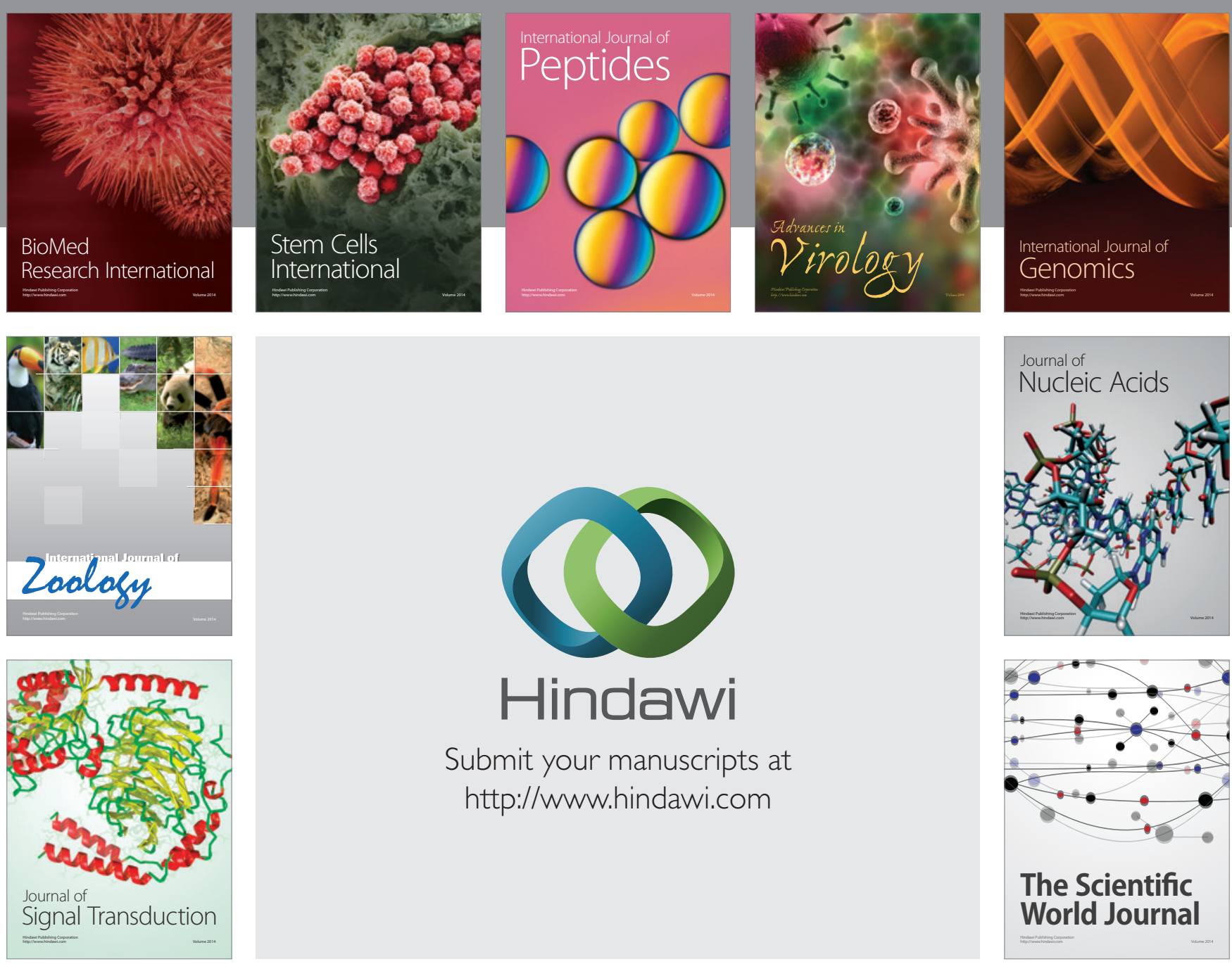

Submit your manuscripts at

http://www.hindawi.com
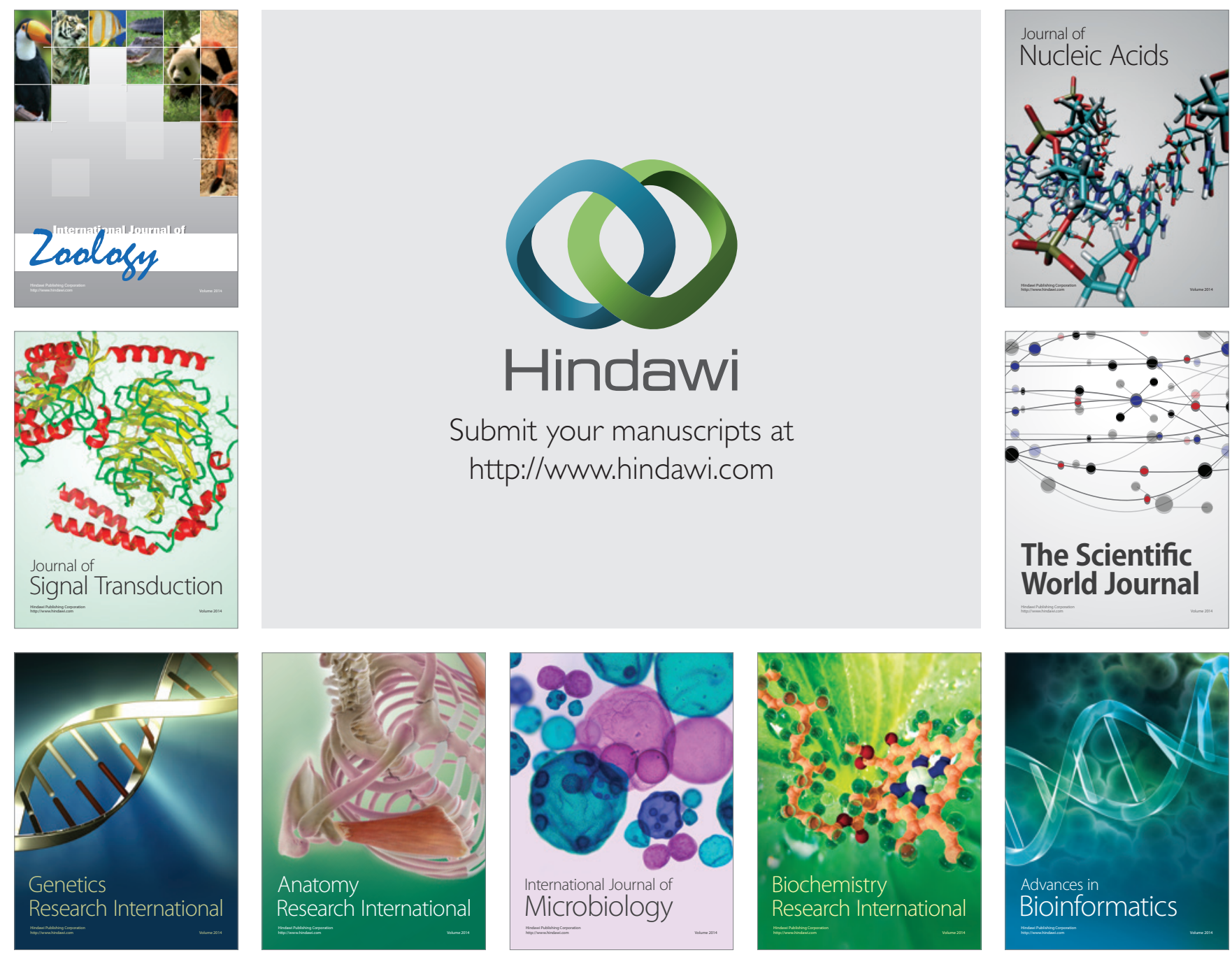

The Scientific World Journal
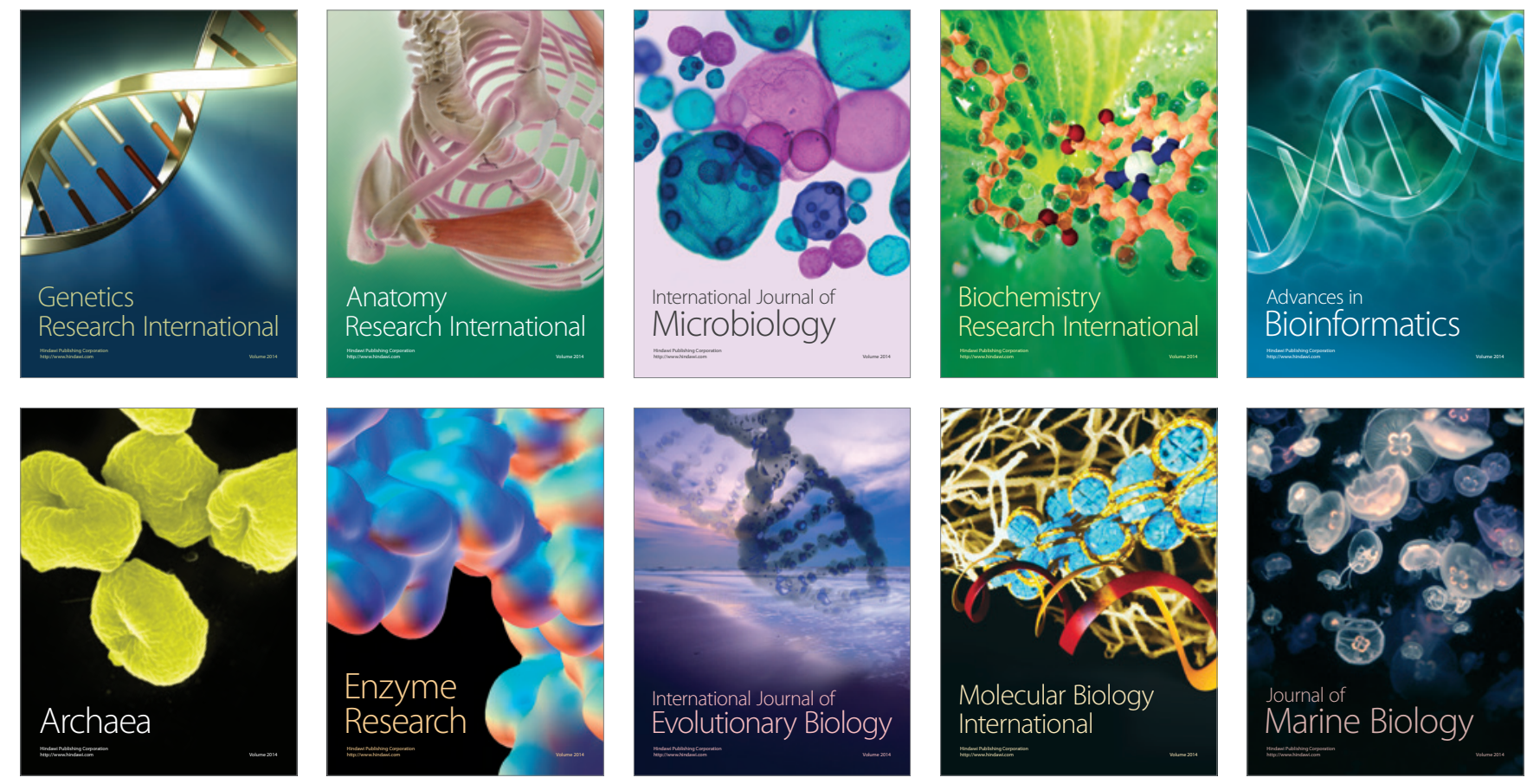